\title{
IMPLEMENTASI STANDAR PENILAIAN DALAM PEMBELAJARAN PAI PADA KURIKULUM 2013
}

\author{
St. Jumaeda \\ FITK Institut Agama Islam Negeri (IAIN) Ambon \\ jumaeda@iainambon.ac.id
}

\begin{abstract}
Abstrak: Tujuan pendidikan yang dimaksud di dalam kurikulum 2013 adalah memberikan ilmu pengetahuan secara utuh kepada peserta didik dan tidak terpecahpecah. Kurikulum ini menekankan pada keaktifan peserta didik untuk menemukan konsep pembelajaran dengan guru berperan sebagai fasilitator. Implementasi kurikulum 2013 diorientasikan untuk mencetak generasi yang siap di dalam menghadapi masa depan, dengan tujuan untuk mendorong peserta didik mampu lebih baik dalam melakukan observasi, bertanya, bernalar, dan mengkomunikasikan (mempresentasikan) apa yang mereka peroleh atau mereka ketahui setelah menerima materi pembelajaran. Kurikulum 2013 adalah pengembangan dari kurikulum berbasis kompetensi dan Kurikulum Tingkat Satuan Pendidikan (KTSP) pada tahun 2006. Perubahan terhadap proses pembelajaran, yang awalnya difokuskan pada eksplorasi, elaborasi, dan konfirmasi, dilengkapi dengan pendekatan keterampilan scienctific knoledge. Akibat dari perubahan tersebut maka, perubahan pada pelaksanaan penilaian Pembelajaran PAI berubah, menjadi penilaian otentik yang mengukur sikap, keterampilan, dan pengetahuan berdasarkan proses dan hasil.
\end{abstract}

Kata Kunci: Penilaian, pembelajaran PAI, Kurikulum 2013

\section{PENDAHULUAN}

Kurikulum merupakan seperangkat rencana dan pengaturan mengenai tujuan, isi dan bahan pelajaran serta cara yang digunakan sebagai pedoman penyelenggaraan kegiatan pembelajaran untuk mencapai tujuan pendidikan tertentu. Tujuan tertentu ini meliputi tujuan pendidikan nasional serta kesesuaian dengan kekhasan, kondisi dan potensi daerah, satuan pendidikan dan peserta didik. Oleh sebab itu, kurikulum disusun sebagai bentuk penyesuaian program pendidikan dengan kebutuhan dan potensi yang ada di daerah. Kurikulum tahun 2013 merupakan pengembangan dari kurikulum berbasis kompetensi tahun 2004 dan pengembangan Kurikulum Tingkat Satuan Pendidikan (KTSP) tahun 2006. 
Kurikulum sebagai acuan dalam pelaksanaan pendidikan, memiliki peran sangat penting yang harus dipahami dengan baik oleh segenap praktisi pendidikan, masyarakat, dan Pemerintah sebagai penentu dan pengambil kebijakan. Terdapat tiga peran penting kurikulum yaitui, 1) peranan konservatif; 2) peranan kritis atau evaluatif; 3) peranan kreatif. Peranan konservatif lebih terkait dengan pandangan konservatif yang menilai bahwa kurikulum berfungsi untuk mentransmisikan dan menafsirkan warisan sosial pada generasi muda. Peranan kritis dan evaluatif kurikulum terkait dengan peran kurikulum sebagai kontrol sosial yang memberikan penekanan pada kerangka berpikir kritis terhadap nilainilai sosial yang tidak relevan lagi dengan kondisi masyarakat kini. Adapun peranan kreatif kurikulum berfungsi menciptakan dan menyusun suatu hal yang baru sesuai dengan kebutuhan masyarakat, baik berupa pelajaran, pengalaman, cara berpikir, kemampuan, dan keterampilan yang baru yang bermanfaat bagi masyarakat (Hamalik: 2008: 13).

Sistem penilaian kurikulum 2013 lebih menghargai kemampuan peserta didik, karena dalam dokumen SKL dijelaskan adanya keseimbangan soft skill dan hard skill yang meliputi aspek kompetensi sikap, pengetahuan, dan keterampilan secara berimbang dan ini membedakannya dengan kurikulum sebelumnya yang memberi penekanan lebih kepada aspek pengetahuan saja. Sistem penilaian juga menunjukkan perubahan. Pada kurikulum 2013, penilaian meliputi proses dalam pembelajaran dan di luar pembelajaran. Hal ini menjadi pekerjaan tersendiri bagi seorang pendidik untuk mampu mengapresiasi keragaman kemampuan yang dimiliki semua peserta didik, sehingga akhirnya tidak ada peserta didik lolos dari pengamatan dan penilaian pendidik (Hidayati, 74:2014).

Kegiatan proses pembelajaran dan penilaian berlangsung secara bersamaan, yaitu pada saat proses pembelajaran belangsung diadakan penilaian proses dan pada akhir proses pembelajaran dilakukan penilaian terhadap hasil belajar yang mencakup aspek kognitif, afektif, dan 
psikomotor serta mengacu pada indikator dan tujuan pembelajaran. Indikator pencapaian yang dirumuskan pada rencana pelaksanaan pembelajaran (RPP) harus mengacu pada kompetensi dasar (KD), standar kompetensi (SK), kompetensi inti, dan standar kompetensi lulusan (SKL). Perubahan yang terjadi dalam proses pembelajaran, yang semula terfokus pada eksplorasi, elaborasi, dan konfirmasi, dilengkapi dengan mengamati, menanya, menalar, menyajikan, menyimpulkan, dan mencipta. Selanjutnya, perubahan yang terjadi pada proses penilaian dalam kurikulum 3013 adalah sebagai berikut: (1) penilaian berbasis kompetensi, (2) pergeseran dari penilaian melalui tes yang mengukur kompetensi pengetahuan berdasarkan hasil saja, menuju pada penilaian otentik yang mengukur sikap, keterampilan, dan pengetahuan berdasarkan proses dan hasil, (3) memperkuat penilaian acuan patokan (PAP), yakni pencapaian hasil belajar didasarkan pada posisi skor yang diperolehnya terhadap skor ideal (maksimal), (4) penilaian tidak hanya pada level KD tetapi juga pada kompetensi inti dan SKL, dan (5) mendorong pemanfaatan portofolio yang dibuat oleh siswa sebagai instrumen utama penilaian.

Kebijakan implementasi kurikulum 2013 diharapkan melahirkan sekolah yang sehat serta terciptanya daya saing sekolah. Sejalan dengan perkembangan teknologi informasi dan pembelajaran berbasis teknologi informasi yang sangat pesat, hendaknya sekolah/madrasah menyikapinya secara saksama, diantaranya melalui peningkatan kualitas proses dan kualitas output pembelajaran agar apa yang dicita-citakan dalam perubahan paradigma pendidikan dapat segera terwujud.

Peningkatan kualitas pembelajaran Pendidikan Agama Islam akan sangat ditentukan oleh hal-hal seperti kesiapan sekolah dalam hal ketersediaan fasilitas penunjang kegiatan pembelajaran, dan profesionalisme guru terutama yang berkaitan dengan kemampuan pemahaman guru dalam melaksanakan program pembelajaran, serta iklim akademik menyangkut situasi yang muncul akibat hubungan antara guru 
dan peserta didik atau hubungan antar-peserta didik, termasuk derajat afeksi positif atau negatif peserta didik terhadap pembelajaran, dan motivasi belajar peserta didik atau dorongan dalam diri peserta didik untuk belajar dan menyelesaikan tugas-tugas, memecahkan masalah maupun mempelajari kompetensi tertentu dalam mata pelajaran dengan sebaikbaiknya berdasarkan standar keunggulan. Untuk meningkatkan kualitas pembelajaran pada program pembelajaran Pendidikan Agama Islam yang diselenggarakan pada Sekolah dan Madrasah terdapat tiga komponen penting program pembelajaran yang saling terkait, yaitu perencanaan pembelajaran, pelaksanaan proses pembelajaran, dan penilaian. Perencanaan pembelajaran merupakan persiapan mengelola pembelajaran yang akan dilaksanakan pada setiap tatap muka. Pelaksanaan proses pembelajaran merupakan kegiatan guru mengelolah pembelajaran di kelas. Kegiatan penilaian dilakukan untuk mengukur dan menilai pencapaian kompetensi serta untuk mengetahui kelebihan dan kekurangan dari proses pembelajaran yang telah dilaksanakan. Program pembelajaran perlu dirancang secara terencana agar pelaksanaan pembelajaran berjalan dengan baik. Karena saling terkait inilah, maka perencanaan pembelajaran yang baik sangat penting untuk menjamin terlaksananya proses pembelajaran yang efektif dan benar.

\section{Metode}

Metode yang digunakan adalah metode deskriptif untuk mendeskripsikan dan menganalisis fonemena, peristiwa, aktivitas sosial, sikap, kepercayaan, persepsi, pemikiran orang secara individual maupun kelompok (Creswell, 2016: 246). Penelitian dengan mengunakan metode kualitatif dengan beberapa deskripsi digunakan untuk menemukan prinsipprinsip dan penjelesan yang mengarah pada penyimpulan.

\section{Penilaian dalam Kurikulum 2013}


Penilaian merupakan hal penting dalam penyelenggaraan pendidikan. Untuk meningkatkan kualitas pendidikan dapat dilakukan melalui peningkatan kualitas pembelajaran yang baik dan akan menghasilkan kualitas belajar yang baik pula. Kualitas pembelajaran dapat dilihat berdasarkan hasil penilaiannya. Penilaian yang baik akan mendorong guru untuk menentukan strategi pembelajaran yang baik, karena itu untuk meningkatkan kualitas pendidikan diperlukan sistem penilaian yang baik.

Berdasarkan peraturan Menteri Pendidikan dan Kebudayaan No 66 tahun 2013 tentang Standar Penilaian Pendidikan, penilaian pencapaian kompetensi pada jenjang pendidikan dasar dan menengah dilaksanakan oleh pendidik satuan pendidikan, Pemerintah dan/atau lembaga mandiri. Penilaian oleh pendidik dilakukan untuk memantau proses, kemajuan peserta didik sesuai dengan kompetensi yang dimilikinya secara berkesinambungan. Penilaian juga dapat memberikan umpan balik kepada pendidik agar dapat menyempurnakan perencanaan dan proses pembelajaran. (Permendikbud. No 66: 2013)

Hasil dari usaha belajar merupakan bentuk perubahan tingkah laku peserta didik, baik secara subtantif yang terkait langsung dengan materi pembelajaran, maupun komprehensip yang terkait dengan perubahan prilaku secara menyeluruh. Perubahan tersebut dapat diamanati secara langsung dan yang tidak dapat diamati secara langsung, ada yang terjadi dalam waktu jangka pendek dan yang terjadi dalam jangka panjang. Dengan demikian penilaian yang digunakan hanya dapat mengungkap sebagian tingkah laku dari keseluruhan hasil belajar yang sebenarnya. Penilaian yang baik dapat menilai hasil-hasil yang autentik yang dapat dilakukan dengan memberikan tes. Penilaian hendaknya dilakukan dengan tepat, teliti, adil dan objektif terhadap hasil belajar sehingga dapat menjadi instrumen untuk mengecek kemampuan peserta didik dalam belajarnya dan mempertinggi prestasi belajarnya. 
Konteks penilaian dalam kurikulum 2013 mengacu pada Permendikbud Nomor 66 tahun 2013 tentang standar penilaian pendidikan. Standar penilaian bertujuan untuk menjamin (1) perencanaan penilaian peserta didik sesuai dengan kompetensi yang akan dicapai dan berdasarkan pada prinsip-prinsip penilaian, (2) pelaksanaan penilaian peserta didik secara profesional, terbuka, edukatif, efektif, efisien dan sesuai dengan konteks sosial budaya, dan (3) pelaporan hasil penilaian peserta didik secara objektif, akuntabel, dan informatif. Standar penilaian ini disusun sebagai acuan penilaian bagi pendidik, satuan pendidikan dan pemerintah pada satuan pendidikan dasar dan menengah. (Permendikbud:2013)

Penilaian dalam kurikulum 2013 lebih menekankan pada penilaian autentik (authentic assesment). Walaupun sebelumnya dalam Kurikulum Tingkat Satuan Pendidikan telah memberi ruang terhadap penilaian autentik, namun dalam pelaksanaan di lapangan belum dilakukan secara optimal. Melalui perubahan kurikulum ini diharapkan penekanan pada penilaian autentik dapat dilakukan oleh pendidik dengan sebenarnya.

Penilaian autentik merupakan usaha untuk mengukur atau memberikan penghargaan atas kemampuan seseorang yang benar-benar menggambarkan apa yang dikuasainya. Penilaian ini dilakukan dengan berbagai cara seperti tes tertulis, portofolio, unjuk kerja, unjuk tindak (berdiskusi, berargumentasi, dan lain-lain. (Peraturan Menteri Pendidikan Nasional No.41 Tahun 2007 Tentang Standar Proses, Glosarium). Salah satu penekanan di dalam kurikulum 2013 adalah penilaian autentik. Seperti yang diketahui penilaian adalah proses pengumpulan berbagai data yang memberikan gambaran mengenai perkembangan peserta didik setelah peserta didik mengalami proses pembelajaran. Penilaian autentik adalah kegiatan menilai peserta didik yang menekankan pada apa yang seharusnya dinilai, baik proses maupun hasil dengan berbagai instrumen penilaian yang disesuaikan dengan tuntutan kompetensi yang ada di 
Standar Kompetensi (SK) atau Kompetensi Inti (KI) dan Kompetensi Dasar (KD) (Kunandar,2013:35-36).

Menurut Kemendikbud (2013:231) penilaian autentik adalah pengukuran yang bermakna secara signifikan atas hasil belajar peserta didik untuk ranah sikap, keterampilan, dan pengetahuan. Istilah penilaian merupakan sinonim dari penilaian, pengukuran, pengujian, atau evaluasi. Istilah autentik merupakan sinonim dari asli, nyata, valid, atau reliabel. Penilaian autentik menggambarkan perubahan dalam diri peserta didik setelah pembelajaran. Dengan demikian, penilaian tidak lagi sekedar pencapaian tujuan, tetapi merupakan suatu usaha untuk memperoleh berbagai informasi secara berkala, berkesinambungan, dan menyeluruh tentang proses dan hasil belajar peserta didik. Penilaian otentik dilakukan untuk mengukur proses pembelajaran dan hasil belajar peserta didik secara menyeluruh. Dalam penilaian otentik digunakan berbagai bentuk penilaian yang merefleksikan proses pembelajaran yang dialami peserta didik, kemampuan peserta didik, motivasi, dan sikap-sikap yang sesuai dengan tujuan pembelajaran.

Dalam proses pembelajaran nyata, penilaian otentik dapat mengukur, memonitor dan menilai secara keseluruhan aspek hasil belajar meliputi ranah kognitif, afektif, dan psikomotor, baik yang tampak sebagai hasil akhir dari suatu proses pembelajaran, maupun berupa perubahan dan perkembangan aktifitas, dan perolehan belajar selama proses pembelajaran di dalam kelas maupun di luar kelas. Hasil penilaian autentik dapat digunakan oleh guru dalam merencanakan program perbaikan (remedial), pengayaan (enrichment), atau pelayanan konseling. Selain itu, hasil penilaian autentik dapat digunakan sebagai bahan untuk memperbaiki proses pembelajaran yang memenuhi Standar Penilaian Pendidikan. 


\section{Pembelajaran PAI Pada Kurikulum 2013}

Pendidikan Agama Islam atau at-Tarbiyah al-Islamiyah adalah usaha bimbingan dan asuhan terhadap anak didik agar kelak setelah selesai pendidikannya dapat memahami dan mengamalkan ajaran agama Islam serta menjadikannya sebagai pandangan hidup. (Daradjat ,1996: 86).

Pendidikan Agama Islam yang terkait dengan struktur kurikulum yang berlaku di Indonesia dimaknai dalam dua sisi: pertama, PAl dipandang sebagai mata pelajaran, sebagaimana yang ada pada kurikulum PAI pada sekolah umum (SD, SMP, SMA/K). Kedua, PAI dipandang sebagai rumpun mata pelajaran seperti Qur'an hadits, fiqh, aqidah akhlak, sejarah kebudayaan Islam, sebagaimana pada kurikulum pendidikan pada madrasah. (Mulyana, 2004: 198).

Kurikulum pendidikan Islam memiliki ciri yang membedakan dengan kurikulum secara umum, Pertama, kurikulum pendidikan Islam menonjolkan dan mengutamakan agama dan akhlak dalam berbagai tujuannya. Materi, metode, alat, dan teknik pengajaran dalam kurikulum pendidikan Islam semuanya bercorak agama. Kedua, cakupan dan kandungan kurikulum pendidikan Islam bersifat luas dan menyeluruh. Ketiga, kurikulum pendidikan Islam menerapkan prinsip keseimbangan di dalam muatan materi keilmuannya. Keempat, kurikulum pendidikan Islam mencakup keseluruhan mata pelajaran yang dibutuhkan peserta didik, baik yang sakral-keakheratan maupun yang profan-keduniaan. (alSyaibany, 1979: 479)

pembelajaran PAI pada Kurikulum 2013 yang mengusung konsep integrasi (terpadu). Keterpaduan pembelajaran PAI meliputi: pertama Keimanan yang memberikan kesempatan kepada peserta didik untuk mengembangkan pemahaman adanya Tuhan sebagai sumber nilai universal. Kedua Pengamalan untuk memberikan peluang kepada peserta didik untuk dapat merasakan dan mempraktikkan nilai universal ajaran Islam dalam menghadapi tugas dan perannya di kehidupan. Ketiga Pembiasaan untuk memberi kesempatan kepada peserta didik untuk 
menjadikan nilai-nilai Islam sebagai sikap dan perilaku sehari-hari. Keempat Rasional, usaha ini untuk memberikan porsi yang lebih besar kepada akal (rasio) untuk memahami dan membedakan berbagai sistem nilai dalam kehidupan. Kelima Emosional, upaya ini untuk menggugah perasaan peserta didik dalam menghayati sikap dan perilaku yang sesuai dengan nilai-nilai Islam dan budaya bangsa. Keenam Fungsional, hal ini menyajikan bentuk semua aspek materi yang memberikan kemanfaatan bagi kehidupan peserta didik. Ketujuh Keteladanan, yang berarti menjadikan sosok guru agama dan orang tua sebagai figur manusia yang berpribadi muslim sehingga dapat dijadikan uswah hasanah. Kedelapan Keterpaduan materi. Keterpaduan yang dimaksudkan adalah pengembangan materi dalam PAI agar ada korelasi antara Al-Qur'an Hadits, Akhlak, keimanan dan fiqih-ibadah sehingga akan menghasilkan manusia muslim yang berkepribadian utuh. (Hidayati, 78-79:2014)

Pengembangan nilai-nilai dan sikap dalam materi pembelajaran PAI dilakukan dengan mengintegrasikan berbagai aspek pembelajaran mulai dari perencanaan meliputi proses pengintegrasian berawal dari SKL dan KI, melalui KD, Silabus, dan RPP mata pelajaran Pendidikan Agama Islam, kemudian pengintegrasian pada pelaksanaan proses pembelajaran, sampai pada pengintegrasian dalam proses penilaian pembelajaran PAI.

Materi pembelajaran PAI dalam kurikulum 2013 tidak mengalami banyak perubahan, yang membedakan dari kurikulum sebelumnya hanya pada istilah yang digunakan seperti; Standar Kompetensi (SK) untuk setiap aspek dalam PAl yang meliputi Al-Qur'an, Aqidah Akhlak, fiqih dan SKI sekarang dalam kurikulum 2013 berubah menjadi Kompetensi Inti, meliputi Sikap Keagamaan (KI 1), Sikap Sosial (KI 2), Pengetahuan (KI 3) dan Keterampilan (KI 4).

Implementasi kurikulum 2013 dalam pembelajaran PAI menuntut kemauan dan kemampuan guru dalam meningkatkan kompetensinya baik kompetensi sosial, profesional, pedagogi, maupun kompetensi 
kepribadian. Hal ini disebabkan materi yang diajarkan adalah Pendidikan yang sarat akan nilai-nilai mulia yang tentunya berbeda dengan mata pelajaran lainnya.

\section{KESIMPULAN}

Kebijakan implementasi kurikulum 2013 diharapkan melahirkan sekolah yang sehat serta terciptanya daya saing sekolah. Sejalan dengan perkembangan teknologi informasi dan pembelajaran berbasis teknologi informasi yang sangat pesat, hendaknya sekolah/madrasah menyikapinya secara saksama, diantaranya melalui peningkatan kualitas proses dan kualitas output pembelajaran agar apa yang dicita-citakan dalam perubahan paradigma pendidikan dapat segera terwujud.

Peningkatan kualitas pembelajaran Pendidikan Agama Islam akan sangat ditentukan oleh hal-hal seperti kesiapan sekolah dalam hal ketersediaan fasilitas penunjang kegiatan pembelajaran, dan profesionalisme guru terutama yang berkaitan dengan kemampuan pemahaman guru dalam melaksanakan program pembelajaran, serta iklim akademik menyangkut situasi yang muncul akibat hubungan antara guru dan peserta didik atau hubungan antar-peserta didik, termasuk derajat afeksi positif atau negatif peserta didik terhadap pembelajaran, dan motivasi belajar peserta didik atau dorongan dalam diri peserta didik untuk belajar dan menyelesaikan tugas-tugas, memecahkan masalah maupun mempelajari kompetensi tertentu dalam mata pelajaran dengan sebaikbaiknya berdasarkan standar keunggulan.

\section{DAFTAR PUSTAKA}

[1] Al-Syaibany, Omar Mohammad al-Thoumy. 1979. Falsafah Pendidikan Islam. Jakarta: Bulan Bintang.

[2] Creswell, Jhon W. ResearchDesign Pendekatan Metode Kualitatif, Kuantitatif dan Campuran,Yogyakarta, Pustaka Pelajar, 2016 
[3] Daradjat, Zakiah. 1996. IImu Pendidikan Islam. Jakarta: Bumi Aksara.

[4] Hamalik, Oemar. 2008. Dasar-Dasar Pengembangan Kurikulum. Bandung: Remaja Rosdakarya

[5] Hidayati, Lili. 2014, Jurnal Insani, Kurikulum 2013 dan Arah Baru Pendidikan Islam, Vol.19 no 1.

[6] Kunandar. (2013) Penilaian Autentik. Jakarta: Raja Grafindo Persada

[7] Mulyana, Rohmat. 2004. Mengartikulasikan Pendidikan M/ai.Bandung: Alfabeta

[8] Peraturan Pemerinta No 66 tentang Standar Penilaian Pendidikan, penilaian pencapaian kompetensi Tahun 2013

[9] Peraturan Pemerinta No 41 tentang Standar Proses Tahun 2007 